\title{
Trade Policies, Investment Climate, and Export Performance
}

\author{
Murat Şeker* \\ Boğaziçi University
}

\begin{abstract}
International trade is a significant source of dispersion in income levels and growth. Although trade liberalization policies during the past 60 years has led to an almost 30fold growth in the volume of international trade, the increase has been unequal among countries. This study investigates how improvements in the investment climate relate to increased export performances of countries. It shows that improvements in regulatory quality, customs efficiency, quality of infrastructure, and access to finance are associated with the competitiveness of firms in international markets. Furthermore, it shows that countries that are relatively more constrained in accessing to foreign markets benefit more from improvements in investment climate. Hence, policies that improve the investment climate have a greater benefit for export sales of countries with lower foreign market access.
\end{abstract}

Keywords: export performance, trade policy, investment climate, institutions, cross country analysis. JEL Classification: F13, F14, F15, F4, O1.

\section{Ticaret Politikaları, Yatırım Ortamı ve İhracat Performansı}

\section{Özet}

Uluslararası ticaret gelir seviyelerinde ve büyümede ülkelerin farklı performans göstermelerinde önemli bir etkendir. Geçtiğimiz 60 yıl boyunca ticareti serbestleştiren politikalar global ticaret hacmini 30 kat arttırmış olsa da, bu artış ülkeler arasında büyük farklar göstermektedir. Bu çalışma, yatırım ortamındaki iyileşmelerin ülke ihracat performansları ile nasıl ilişkilendiğini incelemektedir. Çalışmada, düzenleyici kanunların kalitesi, gümrüklerin verimliliği, altyapı kalitesi, finansman kaynaklarına kolay erişim gibi yatırım ortamını iyileştirecek politikaların firmaların uluslararası piyasalarda rekabet gücü ile nasıl ilişkilendiği gösterilmektedir. Bu tür yatırım ortamını iyileştiren politikalar uluslararası piyasalara erişimde güçlük çeken ülkelerde ihracat gelirlerine nispi olarak daha fazla katkı sağlamaktadır.

Anahtar Kelimeler: ihracat performansı, ticaret politikaları, yatırım ortamı, kurumlar, ülkeler arası analiz. JEL Siniflandirmast: F13, F14, F15, F4, O1.

* Murat Şeker is Chief Financial Officer at Turkish Airlines and Adjunct Professor in the Department of Economics at Boğaziçi University, 34342, Bebek, İstanbul, Turkey. E-mail: muradseker@gmail.com 
7 here is a large collection of theoretical and empirical literature that explores trade as a potential source for the dispersion in income levels across countries. The achievements by several Asian countries of sustained growth while pursuing a strong focus on exports has made these trade-led growth policies highly desired. Studies like Frankel and Romer (1999), Alcala and Ciccone (2004), and Wacziarg and Welch (2008) among many others find positive causal link between openness and high economic performance. ${ }^{(1)}$ Wacziarg and Welch (2008) show that, in 1960 only $22 \%$ of countries representing just $21 \%$ of global population had open trade policies. By 2000 , around $73 \%$ of countries representing $46 \%$ of global population were open to international trade. The liberalization policies led to an almost 30 fold growth in the volume of international trade between 1950 and 2006 - three times faster than the growth in global GDP. However, this increase has not been uniform across countries. Countries in East Asia have posted a greater than 800 percent increase in real exports since the early 1970s, whereas countries in Sub-Saharan Africa have only had a 70 percent increase. The large variation in export performance of countries shows that benefits from being engaged with world markets have been limited to a small number of countries. This study investigates one of the reasons that prevent many countries from reaching the same levels as successful export-oriented countries. It shows in addition to improvements in trade policies, a favorable investment climate is crucial for achieving high export performance.

Many factors affect the export performance of countries, such as being land-locked, far from the global markets, poor in natural resources or having a small size. Limitations caused by these factors are unlikely to be affected by economic policies. For a long time, trade policies including tariff rates, quotas, non-tariff barriers have been the major policy tools to improve export performance. Studies like Hoekman and Nicita (2011) and Anderson and Marcouiller (2002) show that bilateral tariff rates significantly reduce export performance. One purpose of this study is to show how two recently constructed measures of trade restrictiveness affect export performance. Both indices which are based on theoretical foundations are constructed by Kee et al. (2009). ${ }^{(2)}$ The first index is trade tariff restrictiveness index (TTRI) which shows the restrictiveness of domestic trade policies on imports. The second index is market access trade tariff restrictiveness index (MA-TTRI) which shows the ease of foreign market access of the country. Both indices have advantages over simple tariff rates because they are well grounded in trade theory and provide sound aggregate measures of trade restrictiveness.

Despite the substantial decreases in tariff rates since 1960s, the gap in trade performance across countries has not closed. Clarke (2005) and Morrissey (2005) show that the adoption of significant trade liberalization policies in the majority of African countries has resulted in a reduction of import tariff rates from 33\% in the early $1980 \mathrm{~s}$ to $15 \%$ in 2002 . However Gupta and Yang (2006) shows that the share of manufactured

(1) See Berg and Krueger (2003) and Hallaert (2006) for literature surveys on the link between trade and growth.

(2) The methodology developed in Kee et al. (2009) is built on the work of Anderson and Neary (1994, 1996) on trade restrictness. A detailed discussion on the construction of the indices is provided in Kee et al. (2009). 
goods in total exports remains at about 30\% during the same period. Focusing on the low export performance of African countries, Iwanow and Kirkpatrick (2009) conclude that liberalizing trade is not sufficient to achieve high export performance.

Research on the factors that contribute to achieving high export performance other than the traditional trade policies has shown that an investment climate that is conducive to private sector development is crucial for success. One group of studies has looked at the critical role that investment climate plays on the effectiveness of openness for economic development and growth. The macro-level studies by Rodriguez and Rodrik (2000) and Rodrik et al. (2004) show that excluding institutional differences across countries when analyzing the relationship between openness and economic performance would be inconclusive. More recent studies by Dollar and Kraay (2003), Chang et al. (2009), and Freund and Bolaky (2008) show that although openness is beneficial for generating high income and growth, its impact varies with the conditions of investment climate.

Building on the work of North (1990), a second group of studies investigates the impact of investment climate on international trade flows. Using a gravity model, Anderson and Marcoullier (2002) show that bilateral trade volumes are positively influenced by the trading countries' institutional quality. Francois and Manchin (2013) analyze the influence of institutions, infrastructure, and trade policies on the patterns of bilateral trade. They empirically show that the dependence of export performance on indicators of investment climate is far more important than the dependence on tariff rates in explaining the variations in North-South trade relationship.

Among the various aspects of investment climate trade facilitation is also closely related to trade performance. The reforms in this area have been at the forefront of the discussions on reducing the costs of trading. Using a gravity model specification, Wilson et al. (2003) estimate the impact of trade facilitation on trade flows and find large increases in trade and growth rates from trade facilitation reforms. Djankov et al. (2010) find that each additional day a product is delayed prior to being shipped reduces trade by at least one percent. Limao and Venables (2001) and Iwanow and Kirkpatrick (2009) show that inefficient trade facilitation is one of the main factors behind low trade performance of Sub-Saharan African countries. They also highlight the importance of other reforms including the quality of the regulatory environment and the quality of the basic infrastructure. Infrastructure is important because unexpected losses due to water or electricity outages, inefficient telephone connections or roads could increase the cost of production which eventually leads to lower competitiveness in international markets. All these studies present evidence that points to the importance of a favorable investment climate comprised of efficient institutions, good trade facilitation, and high quality infrastructure to attain high competitiveness in international markets. High costs of trade transactions due to inefficiencies in investment climate attenuate the ability of countries to establish strong links with global markets.

Combining data from a variety of sources and including a diverse group of countries with different income levels and from different regions of the world, I analyze how economic policies on investment climate affect the export performance of countries. I focus on six indicators each representing a different aspect of investment climate: regulatory 
quality, trade facilitation, entry regulations, access to finance, infrastructure, and property rights. Although a number of studies analyze how some of these indicators affect export performance individually, there is no study that investigates them under the same setup; neither is there work that shows how these investment climate factors interact with the restrictiveness of foreign market access in affecting export performance. Moreover, this is the first study that uses two new measures of trade restrictiveness (TTRI and MATTRI) to investigate the relationship between trade policies and investment climate. I show that a favorable investment climate not only improves export performance, but also reduces the distortions caused by restrictive foreign market access policies. This finding highlights the importance of reforms in investment climate for countries with lagging trade performance.

The rest of the paper is organized as follows. Section 2 explains the methodology and specifications used in the analysis. Section 3 describes the data and section 4 presents the analysis results. Alternative specifications and robustness tests are presented in section 5. Section 6 concludes.

\section{Methodology and Variables of Interest}

The empirical model investigates the role of investment climate in alleviating the distortions on export performance caused by restrictive trade policies. The data used in the analysis are from a short panel of three years of observation from 2006 to 2008 for 137 countries. The primary estimation method that I apply is pooled ordinary least squares method (OLS). This method is appropriate when in addition to standard assumptions of OLS method, homoscedasticity and no-serial correlation assumptions over the time dimension are satisfied. However in panel datasets, the standard errors are likely to be correlated over time and hence not independent and identically distributed. For this reason, I correct for the standard errors by clustering over countries. Failure to control for this error correlation might lead to underestimation of standard errors. I include two year dummies for 2006 and 2007 to control for the aggregate year effects. The estimation equation that is used in the analysis is presented below in which subscript $i$ represents country and $t$ represents time,

$$
\begin{aligned}
\text { Export }_{i t} & =\beta_{0}+\beta_{1} \operatorname{Re} \text { alGDP }_{i t-1}+\beta_{2} \text { Area }_{i}+\beta_{3} \operatorname{Re} \text { moteness }_{i}+\beta_{4} \text { ExportGrowth }_{i t-1, t-2}+\beta_{5} \text { TTRI }_{i t-1} \\
& +\beta_{6} \text { MATTRI }_{i t-1}+\beta_{7} \text { Indicator }_{i t-1}+\beta_{8} \text { MATTRI }_{i t-1} * \text { Indicator }_{i t-1}+\beta_{9} d_{2006}+\beta_{10} d_{2007}+\varepsilon_{i t} .
\end{aligned}
$$

In this equation export performance of countries is measured by log of export sales (Export) in constant 2005 US dollars which is obtained from World Bank Development Indicators (WDI). By measuring exports in constant US dollars, like Dollar and Kraay (2003), I assume that exported goods' prices are roughly equalized across countries. In the estimation, real export sales at period $t$ is regressed on the independent variables at period $t-1$ and at $t-2$. 
In the equation MATTRI shows the log of market access-trade tariff restrictiveness index (shortly market access index). Kee et al. (2009) construct this index as a measure of trade barriers imposed by trading partner countries on the products of the exporting country. The index is presented in World Trade Indicators (WTI) of the World Bank from 2005 to 2007 and it measures the equivalent uniform tariff of trading partners facing the exporting country that would maintain the imports of the trading partners at a constant level, including preferential tariffs. It is weighted by import values and import demand elasticities of trading partners and expressed as a tariff rate. A low value of the index indicates low trade barriers (or high market access) faced by the country's exporters when selling their products abroad. I use this index as a measure for restrictiveness of trade policies in accessing foreign markets.

In the equation TTRI is the log of trade tariff restrictiveness index (shortly tariff index). This index is also constructed by Kee et al. (2009) and presented in WTI. ${ }^{(3)}$ Tariff policies adopted at home can also contribute to the export performance of a country if exporters are likely to use imported intermediate goods. In an analysis of U.S. firms, Bernard et al. (2007) find that $41 \%$ of exporting firms also import while $79 \%$ of importers also export. Using a firm level dataset from 43 developing countries, Şeker (2012) shows that 35 percent of firms that are engaged with international markets through exporting or importing perform both activities. He notes that there could be complementarities between two activities that generate productive and fast-growing firms. There are studies that relate imports to higher productivity such as Halpern et al. (2015), Amiti and Konings (2007) and Kasahara and Rodigue (2008). Halpern et al. (2015) using firm level data from Hungary, find that two-thirds of productivity increase caused by importing is attributable to an increase in the variety of intermediates used. Amiti and Konings (2007), using data from Indonesia, show that reducing input tariffs increases productivity three times more than a reduction in output tariffs. Thus, low domestic tariff rates decrease the cost of imports which could increase productivity and as a result can stimulate exports.

Tariff indexes (TTRI) summarize the impact of each country's non-discriminatory trade policies on its aggregate imports. TTRI indicates the degree of domestic inefficiency caused by the trade regime. It is calculated as an equivalent uniform tariff of a country's tariff schedule that would keep domestic import levels constant. Product level tariffs are weighted by import shares and expressed as a tariff rate. In the empirical analysis, I show how both MA-TTRI and TTRI distort export performance of countries and investigate how various investment climate factors interact with this relationship. This is the first paper that uses these indices to analyze their direct effects on export performance and at the same time shows how they affect the contribution of investment climate on export performance.

Dollar et al. (2006) show that a favorable investment climate decreases the sunk costs of exporting and eventually leads to higher participation in export markets. Such an environment can also increase export volumes by reducing the distortions of the

(3) The TTRI index used here is for the most favored nation which is the commonly used tariff measure in the literature. 
restrictive market access policies. The ability of a country to improve its foreign market access is limited to making multilateral and bilateral agreements with potential partner countries. When there is limited room to improve these market access policies, attaining a favorable investment climate can contribute to increase comparative advantage and can achieve high export performance. I focus on several aspects of investment climate. The choice of these indicators was motivated by the existing studies in the literature. As it was briefly discussed in the introduction, there are studies that show how institutions, infrastructure, trade facilitation, and regulations affect export performance. I choose the following six indicators for the analysis (denoted as Indicator in the estimation equation): regulatory quality, financial development, business entry regulations, exports facilitation, quality of infrastructure, and property rights.

The first indicator is regulatory quality, which is obtained from Worldwide Governance Indicators (WGI). This index captures the ability of a government to formulate and implement sound policies and regulations that permit and promote private sector development. Details of how this indicator is constructed are presented in Kaufman, Kraay, and Mastruzzi (2009). The indicator is standardized between -2.5 and 2.5 with high scores corresponding to better outcomes. The second indicator measures financial development. It is the log of the ratio of money and quasi money (M2) to GDP which is collected through World Bank's World Development Indicators (WDI). This is a standard macro level indicator of financial development. The third indicator is an index of business entry regulations. It is collected through the "Doing Business" surveys of the World Bank and it measures the number of procedures it takes to start a business. The fourth indicator is time to export, which is a measure of a country's customs efficiency. It is measured as the log of the duration (in days) of the goods to be exported. It is also collected through the "Doing Business" surveys. The fifth indicator is the quality of overall infrastructure (e.g. transport, telephone, and energy). This indicator is collected by the World Economic Forum's Global Competitiveness report. The last indicator measures protection of property rights. It is obtained from the Economic Freedom of the World database. However the original data is collected by the World Economic Forum. The last two indicators vary between 1 and 7 where 1 corresponds to lowest rating. Each investment climate factor is included separately in regressions which are represented by Indicator in the estimation equation above.

In the estimation, in addition to trade policy variables and indicators for investment climate, I control for the size of the country with two measures: log of real GDP (RealGDP) and log of its area (Area). Real GDP is measured in constant 2005 US dollars at PPP. I follow Dollar and Kraay (2003) and Alcala and Ciccone (2004) in using the PPP for converting GDP values into US dollars. Presenting GDP in PPP is more appropriate than deflating with market exchange rates for cross-country analysis. As for the area of the country, studies like Rodrik (1998) and Frankel and Rose (2000) show that area has a significantly negative impact on openness. Large countries are less likely to trade with others because of relatively higher domestic demand and higher transport costs of exporting. Moreover small size limits the country's possibilities to diversify production. Another explanatory variable is the remoteness of the country from the rest 
of the world. Anderson and Van Wincoop (2003) show that a country's trade with any partner country depends on its average distance from the rest of the world. Following the method introduced in Head (2003), I define a remoteness index. ${ }^{(4)}$ This index also partially controls for the regional differences of countries. The log of this index -labeled as Remoteness- is included in the estimation. Finally, I control for the past export growth performance of the country (Export Growth) which is computed as the log of past real export growth rate between periods $\mathrm{t}-1$ and $\mathrm{t}-2$. This variable can control for the positive steps taken in the past to spur export performance such as implementation of trade liberalization policies, expansion of trade into new markets, exports of new products, or establishing trade agreements.

Endogeneity is a major concern in the estimation of cross-sectional or short-panel datasets. Especially for the relationship between GDP and export, gravity models assume that the volume of trade between two trading countries is positively related to the GDP levels of these countries (see Anderson and Van Wincoop, 2003). On the other hand, studies by Freund and Bolaky (2008) and Chang et al. (2009) among many others find positive income effects of trade openness. Short nature of the panel prevents application of certain panel estimation methods like fixed effects or GMM methods. To mitigate the endogeneity problems I use lagged independent variables in the estimations.

The main hypothesis I test in the analysis is whether the interaction of market access index with the investment climate indicator is significantly negative. The negative interaction term shows that any improvement in investment climate is associated with higher export performance of countries with more difficult foreign market access.

\section{Data}

The dataset covers three years of observations between 2005 and 2007 for 137 countries. The list of countries is given in Table 1. However there are variables which have missing observations for some of the countries. The data include countries from six regions of the world and five income groups. These groups are constructed according to World Bank classifications. The regional and income distribution of the countries included in the dataset for 2005 is presented in Table $2 .{ }^{(5)}$ In Table 3, I present the list of variables included in the analysis and their sources. The export data was obtained from 2006 to 2008, whereas the explanatory variables are from 2005 to 2007 when possible. Although some of the variables are available for a longer time span, the analysis is limited by the availability of the data for TTRI and MA-TTRI from WTI, which are only available for 2005-2007. Data from global competitiveness reports on the quality of infrastructure is only available for 2008. The last column in Table 3 shows the expected signs of the relationships between the explanatory variables and export sales.

(4) Remoteness is defined as remote ${ }_{i}=1 /\left(\Sigma_{j} G D P_{j} /\right.$ Dist $\left._{i j}\right)$ there Dis $\phi_{j}$ the distance between two countries $i$ and $j$. Djankov et al. (2010) use this index in their estimation of a modified gravity equation. They argue that remoteness is correlated with factoryto-port time delays hence excluding it from the analysis would produce biased estimates of the impact of trade facilitation on export sales. 
Descriptive statistics for the variables used in the analysis are presented in Table 4. In the table, I present both within and between country variations for each variable. The data shows that for most of the variables, variation is quite small compared to the overall variation which is due to the few number of time periods.

\section{Analysis and Results}

Collinearity between the explanatory variables could bias the estimation results and make it difficult to identify the relationship between each explanatory variable and export sales. I present the correlation matrix between the variables in Table 5. The table shows that investment climate indicators are highly correlated with each other. Thus, in each estimation, I include only one investment climate indicator. The estimation results with the pooled OLS method are presented in Table 6. GDP is a strong correlate of high export performance - a common finding of gravity models. On the other hand, large and remote countries export less. A ten percent increase in the remoteness of a country is associated with a decrease in export sales of 4-5 percentage points across the specifications. These findings are in accordance with the results from Djankov et al (2010) and Iwanow and Kirkpatrick (2009). Past export growth is also a strong correlate of current export performance. Lastly, the trade restrictiveness index, which measures the stringency of domestic trade policies on imports, is negatively related to exports. This could be explained by the complementarity between importing and exporting activities resulting from exporters' extensive usage of imported intermediate goods.

Redding and Venables (2003) emphasize the importance of foreign market access as a factor of export growth. In their theoretical model, they define foreign market access of an exporting country as the sum of market capacities of all partner countries. They find that a substantial part of the differential export growth of numerous countries since 1970 can be attributed to variations in the rate at which their foreign market access has grown. In Table 6, MA-TTRI shows the effects of foreign market access. In four of the six specifications, the coefficient of this index is negative and significant, which shows that difficulties in market access is significantly associated with decrease in export performance. A ten percent increase in market access relates to 2 to 8 percentage points increase in exports. Among the investment climate indicators, the ones that have significant coefficients are in accordance with the empirical findings in the literature. Better regulatory quality, quality of infrastructure, and protection of property rights lead to higher export sales, whereas the inefficiencies in trade facilities decrease exports. The interaction terms between market access and investment climate indicators are significant with the expected signs in all specifications. They show that improvements in investment climate are associated with larger contributions to increasing export performance of countries with low foreign market access relative to those with high foreign market access. In countries with difficult access to foreign markets, firms that export need to be more competitive and have higher efficiency levels than those in easier market access (because they are facing higher fixed and sunk costs to export). When the investment climate improves, these more constrained firms can start to export and thus the benefit to 
them is higher than to those firms with easier market access (countries with lower fixed and sunk costs). Improving investment climate helps all exporters but the contribution is relatively higher to those that are relatively more constrained.

We can compare the total impacts of each investment climate indicator on export performance. Using the estimation results from Table 6, I compute total impacts of one standard deviation change in investment climate indicator on growth rates of export sales. ${ }^{(6)}$ To show how countries with different levels of foreign market access benefit from this improvement, I compare the 25 th and $75^{\text {th }}$ percentiles of foreign market access restrictiveness index which correspond to 2 and 5.5 percent tariff rates respectively. ${ }^{(7)}$ The difference between growth rates of export sales generated by the change in each investment climate indicator for the two values of foreign market access index are given in Table 7. The table shows that a country in the $75^{\text {th }}$ percentile of market access index distribution benefits from one standard deviation improvement of regulatory quality by 10 percentage points more than a country in the $25^{\text {th }}$ percentile of the distribution. Similarly the difference in the gain of export revenues between the countries that are in $75^{\text {th }}$ and $25^{\text {th }}$ percentiles of market access index distribution from a one standard deviation improvement in business entry regulations is 12.4 percentage points. The impacts of the other investment climate indicators are of similar magnitudes. These results show that improvements in investment climate are associated with reducing the barriers of trade and the relation between these investment climate variables and export performance is stronger in countries with lower foreign market access.

The interaction terms also allow us to measure how distortions caused by restrictive market access policies vary with different levels of investment climate measures. A comparison of the $25^{\text {th }}$ and $75^{\text {th }}$ percentiles of the distribution for each investment climate indicator shows that one standard deviation decrease in foreign market access (which means an increase in MA-TTRI) leads to almost a 19 percentage points decrease in export sales for a country in the $25^{\text {th }}$ percentile of the distribution for regulatory quality. However this decrease is only 5 percentage points for a country in the $75^{\text {th }}$ percentile. Similarly, the decrease in export sales for a country in the $25^{\text {th }}$ percentile of the distribution for starting a business indicator is almost 2 percentage points, whereas in the $75^{\text {th }}$ percentile, the decrease is almost 18 percentage points. The differences between the $75^{\text {th }}$ and $25^{\text {th }}$ percentiles for all investment climate indicators are presented in Table 8. These findings show that a strong investment climate works as a cushion and reduces the distortions caused by unfavorable foreign market access.

It is intuitive to expect that improvements in IC would also help reduce the impact of trade restrictions applied at home. Thus the interaction between TTRI and IC could be significant. Alternatively I analyze three specifications including ${ }^{(8)}:$ i-) only MATTRI and its interaction term with IC variables, ii-) excluding MATTRI from the analysis

\footnotetext{
(6) The standard deviation in the investment climate indicators are calculated over the largest regression sample which corresponds to 205 observations. The change is applied in the direction of improvement in the investment climate indicator.

(7) The formula applied is as follows:

$\Delta \operatorname{Export}_{i t}(75)-\Delta$ Export $_{i t}(25)=\beta_{8} * \Delta$ Indicator $_{i t-1} *\left(\log \left(\right.\right.$ MATTRI $\left._{i t-1}(75)\right)-\left(\log \left(\operatorname{MATTRI}_{i t-1}(25)\right)\right)$.

(8) All these alternative estimation results are available upon request.
} 
and including only TTRI and its interaction term with IC variables, iii-) including both MATTRI and TTRI but only the interaction between TTRI and the IC variables.

Estimation results of specification (i) continue to hold as in Table 6. In none of the other specifications the interaction terms between TTRI and IC variables are significant. Tariffs and other non-tariff barriers applied at home (proxied by TTRI) are constrains on imports. Yet, there is a complementarity relation between imports and exports, as exporters usually form a big part of importers (this finding is analyzed in Şeker (2012)). That's the reason why TTRI had negative and significant coefficient in all specifications in Table 6. However, the interaction term aims to capture how much improving investment climate at home help alleviate trade barriers faced by exporters. Trade barriers faced by exporters are the tariffs and other non-tariff barriers imposed by the importing country, not the exporting country (proxied by MATTRI in our analysis). Hence it is appropriate to use MATTRI as the main variable of interest since we focus on export performance of the home country.

I used alternative indicators for some of the investment climate factors introduced above to see whether the results were specific to the variables used. These alternative variables are rules of law from WGI, logistic performance index (LPI) from WTI, a measure of infrastructure from Enterprise Surveys database, and a measure of property rights from index of economic freedom (IEF). The information contained in these variables are similar to the ones presented in Table 6, however they are obtained from different sources. ${ }^{(9)}$ Rule of law captures the extent to which agents have confidence in and abide by the rules of society, the quality of contract enforcement, the police and the courts, as well as the likelihood of crime and violence. This indicator is also standardized between -2.5 and 2.5 with high scores corresponding to better outcomes. The second indicator is the logistic performance index (LPI), which reflects the overall performance of a country's logistics environment. ${ }^{(10)}$ It is collected by the WTI. For this standardized variable, higher values correspond to a better logistic performance. Although the methodology applied to collect the data is similar to time to export data from DB, the content of LPI is much broader. The third indicator is an alternative for infrastructure measure which is obtained from the Enterprise surveys of the World Bank. ${ }^{(11)}$ These surveys are conducted only to firms in developing countries. The question used in the analysis is the log of the percentage of sales lost due to power outages in each country. The final alternative indicator is a measure of property rights from the Index of Economic Freedom database. It measures the degree to which a country's laws protect

(9) The rule of law is an exception. Although it is collected through WGI, the variables used in constructing rule of law are different than the ones used for regulatory quality. I have included this indicator as it has been used in several studies such as Dollar and Kraay (2003) and Freund and Bolaky (2008) as a proxy for institutional quality and it significantly relates to welfare of countries.

(10) LPI is formed of the following subcategories: efficiency of the customs clearance process, quality of transport and transportrelated infrastructure, ease of arranging competitively priced shipments and competence, quality of logistics services, and tracking ability and timeliness of shipments.

(11) See www.enterprisesurveys.org for the methodology and data coverage. Each country is surveyed once and the survey year varies across countries. 
private property rights and the degree to which its government enforces these laws. Each country is graded in a $0-100$ scale where higher grade means better property rights. In the analysis log of this indicator is used. This measure differs from the property rights measure in Economic Freedom of the World in its source of collection. ${ }^{(12)}$ The data for infrastructure is available for 2005 to 2008 depending on the survey year. All other data are available for 2005-2007 periods. The results of these alternative investment climate indicators are presented in Table 9. Since all of these indicators except the rule of law are obtained from different sources, it is not possible to compare their contribution with those variables presented in Table 6 . However, in all specifications, investment climate indicators have the expected signs and the interaction terms are significant which is in accordance with results in Table 6 .

\section{Alternative Specifications and Panel Estimation Methods}

In this section, I perform several tests to show the robustness of the findings and to alleviate the endogeneity problem. There are several linear models for panel data that can be applied. The fixed-effects panel model is attractive as we can obtain consistent estimates of the variables provided that they are time varying, even if the regressors are endogenous. However, in this method the coefficients of the regressors with little variation over time will be imprecisely estimated. In fact, Table 4 showed that over time, variation in each variable was quite low relative to the cross-sectional variation. Thus, using fixed effects method would give imprecise results. Since the number of periods is only three for most of the countries, I use pooled feasible generalized squares (FGLS) and random-effects models. In these models, the unobserved country specific effect is assumed to be purely random. The FGLS methods, which are also known as population-averaged estimators and random-effects models are appropriate to use when the error terms are heteroscedastic and serially correlated over time. These estimators allow over time correlation for each country. For both specifications, I assume a first order autoregressive process on error terms which allows the correlation of error terms over time. I also present robust standard errors.

Estimation results with the population averaged estimator are presented in Table 10 and the results with random effect model are presented in Table 11. ${ }^{(13)}$ Both panel estimation methods give similar results. They are in accordance with the pooled OLS results. In both methods, magnitudes of the coefficients of market access rates, the investment climate indicators and their interaction are much smaller when compared to the results in Table 6. Also, the standard errors decrease in panel methods, which shows the improvement in the efficiency of the results.

Next, I include additional variables and test the results with different sub-samples to show the robustness of the results. The Economic Freedom of the World report publishes

\footnotetext{
(12) See Berg and Krueger (2003) and Hallaert (2006) for literature surveys on the link between trade and growth.

(13) In population-averaged estimator method, infrastructure variable did not converge; hence it is excluded from the table.
} 
an index for the size of the trade sector relative to its expected size. Using regression analysis, an expected size of the trade sector (summation of import and export) is derived based on the population and geographical size of the country and its location relative to the concentration of world GDP. This expected size is compared to the actual size of trade. This procedure allocates higher ratings to countries with large trade sectors compared to what would be expected, given their population, geographic size, and location. ${ }^{(14)}$ The level of knowledge capital in the country, the percentage of population speaking a major global language such as English, and the legal origin of the country could affect the country's export performance. Expected size of trade could be used to alleviate the omitted variable bias by controlling for these factors that are likely to affect trade but cannot be controlled by factors like geography, size, and trade policies.

Dollar and Kraay (2003) show that in countries like China, a large share of exports come from firms with foreign direct investment. Moreover, UNCTAD (2002a, b) reports illustrate that FDI can be expected to contribute to enhancing a country's competitiveness in international markets by increasing the technological content of exports. FDI is usually directed towards either higher-value-added activities in newly targeted industries or higher-productivity and higher-technology activities within already targeted industries. Hence these establishments can induce technological spillover to domestic firms which can increase their competitiveness. Fugazza (2004) shows that contribution of FDI to capital formation has a positive impact on export performance. I include net inflows of foreign direct investment (FDI) to the country in the estimations. The data for FDI is obtained from the WDI. Estimation results including both expected size of trade and FDI investment are presented in Table 12. Results show that both variables are significantly related to export sales and do not distort the relationship between market access and the investment climate indicators. These two variables are included in all the robustness tests through the rest of the paper.

Firms incur additional costs to export their products. As Dollar et al. (2006) shows, improvements in investment climate reduce these costs. However, it might take longer than a year for firms to respond to some of these improvements. Although responding to improvements in reductions of time to export could be fast, it would take longer to see the effects of improvements in regulatory quality or property rights. I use two year lag values of the explanatory variables instead of one year to control for the possible lag in responding to changes in investment climate factors. The result of this specification is presented in Table 13. Although the sample size drops almost by half, the interaction terms are still significant with the expected signs.

Trade agreements can reduce the barriers to exporting and increase engagement with the rest of the world. Thus MA-TTRI is likely to be high in a country that is excluded from such agreements. The World Trade Organization collects data on number of reciprocal preferential trade agreements both regional and bilateral in goods and services. This data is available after 2006. The median number of trade agreements for

(14) See Economic Freedom of the World Report for construction and a description of this index. 
2006 and 2007 period is three. Average MA-TTRI in countries that have less than three agreements is $4.3 \%$ and in countries that have at least three agreements, it is $3.4 \%$. Not controlling the trade agreements in the analysis could bias the estimation results and could inflate the negative relationship between MA-TTRI and export sales. In the first test with subsamples, I perform the analysis restricting the sample to those countries that have more than three trade agreements. The results are presented in Table 14. They show that even among countries that have established trading relationships with partner countries, improvements in investment climate are still associated with a relatively larger contribution to export performance of countries with lower market access. Similar results are obtained if the analysis is restricted to countries that have a higher than average number of trade agreements, which is 7.5. In this alternative specification, although the interaction terms for infrastructure and property rights have the expected signs the coefficients are no longer significant.

The second test with the sub-sample is performed for the income groups. The income level of country can affect market access. Richer countries would have relatively easier access to foreign markets and they export more. Average MA-TTRI in high and uppermiddle income countries in 2005 is $4.8 \%$, which is 2.3 percentage points lower than the levels in low and low-middle income countries. Although the difference diminishes over the years, it could affect the estimation results. To control for the effect of the income level, in Table 15, I restrict the sample to upper-middle and high income group countries. The results show that the relationship between market access and investment climate still holds for countries that are relatively richer.

The tariff rates and market access rates used in the analysis do not include non-tariff barriers. However, they can play a significant role in obstructing firms from exporting. WTI constructs two indices overall: trade restrictiveness index (OTRI) and market access-overall tariff trade restrictiveness index (MA-OTRI) which include non-tariff measures such as price control measures, quantity restrictions, monopolistic measures, technical regulations, and agricultural support. Both indices are measured as a tariff rate. These indices provide a more comprehensive measure of barriers to international trade. The results of using these alternative indices are presented in Table 16. A comparison of the results from Table 16 and Table 12 shows that MA-OTRI is more distortive for export sales for most of the investment climate indicators. In Table 16, four of the six investment climate factors are significantly related to reduction in the losses of exports that are caused by difficulties in market access. The relationship is no longer significant for access to finance and for entry regulations. The results with overall indices show that improvements in investment climate are related to reductions in the distortions caused by both tariff and non-tariff related barriers.

The potential endogeneity problem between aggregate GDP and export sales was briefly discussed in section 2. I use lagged value of GDP in the estimation to alleviate this problem. To provide further robustness on the relationship between GDP and exports, I perform two tests. First, I apply a distributed lag model to show the long term effects of GDP on export performance. I include both one year and five years (and in another specification one year and ten year) lag values of GDP. The results show that 
long term effects of GDP on export are significantly positive. In a second test, I remove GDP from the estimation and replace the dependent variable with export share. In one specification I use real export share measured as real exports divided by real GDP in PPP, and in another one I use nominal export share measured as nominal exports divided by nominal GDP. In both specifications the results are quite similar to the main estimation results from Table $6{ }^{(15)}$ Finally, to alleviate the concerns with serial correlation and the possible effects of the noise in the data over time, I use average values of the dependent and all explanatory variables included in the analysis for years 2005 to 2007 and perform simple OLS estimation. The results of these estimations, which are available upon request, are in accordance with the main findings. Investment climate factors are significantly related to export performance and they reduce the distortions cause by restrictive market access.

\section{Conclusion}

Trade volumes in the last 60 years have increased significantly. The vast trade liberalization policies undertaken around the world have substantial contribution to this increase. Policy makers now have to make more complex decisions, as policies solely focused on eliminating trade barriers are no longer sufficient to attain high competitiveness in international markets. To improve competitiveness, emphasis must be given to policies that will improve investment climate. These policy areas ensure access to backbone infrastructure services, improvements in customs facilities, reduction in transactions costs, and improvements in access to external finance for firms. Improvements in these areas lead to increases that complement trade liberalization policies in creating higher success in international markets.

In this paper I show that restrictions in foreign market access and domestic tariff policies are negatively related to export performance. Then I incorporate six indicators that measure different aspects of investment climate. These indicators are regulatory quality, trade facilitation, entry regulations, access to finance, infrastructure, and property rights. Improvements in these indicators are not only related to an increase in export sales but are also related to a reduction in the distortions caused by restrictive foreign market access policies. Although the estimation results are robust and they show the strong correlation between trade barriers and export performance, they should be evaluated with care as it is difficult to derive a causal relationship using such a limited cross-sectional data. The significant interaction between investment climate indicators and market access measure shows that reforms that improve investment climate enhance countries' abilities to respond to the export market opportunities and they contribute more to countries with low levels of market access.

(15) This should be expected as the elasticity of export with respect to GDP is close to one in all specifications. 


\section{References}

Alcala, F. and Antonio, C. (2004). "Trade and Productivity," Quarterly Journal of Economics, 119(2): 13-646.

Amiti, M. and Jozef, K. (2007). "Trade Liberalization, Intermediate Inputs, and Productivity: Evidence from Indonesia," American Economic Review, 97(5): 1611-1638.

Anderson, J.E. and Douglas, M. (2002). "Insecurity and the Pattern of Trade: An Empirical Investigation," Review of Economics and Statistics, 84(2): 342-352.

Anderson, J.E. and Neary, J.P. (1994). "Measuring the Restrictiveness of Trade Policy," World Bank Economic Review, 8(2): 151-169.

------, (1996). "A New Approach to Evaluating Trade Policy," Review of Economic Studies, 63(1): 107-125.

Anderson, J.E. and Wincoop, E.V. (2003). "Gravity with Gravitas: A Solution to the Border Puzzle,” American Economic Review, 93(1): 170-192.

Berg, A. and Krueger, A. (2003). "Trade, Growth, and Poverty: A Selective Survey," IMF Working Paper 03/30, International Monetary Fund.

Bernard, A.B., Jensen, J.B., Redding, S.J., and Schott, P.K. (2007). "Firms in International Trade," Journal of Economic Perspectives, 21(3): 105-130.

Clarke, G.R.G. (2005). "Beyond Tariff and Quotas: Why don't African Manufacturing Enterprises Export More?” World Bank Policy Research Working Paper 3617, World Bank.

Chang, R., Kaltani, L., and Loayza, N.V. (2009). "Openness can be Good for Growth: The Role of Policy Complementarities," Journal of Development Economics, 90: 33-49.

Djankov, S., Freund, C., and Pham, C.S. (2010). "Trading on Time," The Review of Economics and Statistics, 92(1): 166-173.

Dollar, D. and Aart, K. (2003). "Institutions, Trade, and Growth," Journal of Monetary Economics, 50(1): 133-162.

Dollar, D., Hallward-Driemeier, M., and Mengistae, T. (2006). "Investment Climate and International Integration," World Development, 34(9): 1498-1516.

Francois, J. and Manchin, M. (2013). "Institutions, Infrastructure, and Trade," World Development, 46: 65-175. 
Frankel, J.A. and Rose, A.K. (2000). "Estimating the Effect of Currency Unions on Trade and Output," NBER Working Paper 7857.

Frankel, J.A. and Romer, D. (1999). “Does Trade Cause Growth?” American Economic Review, 89(3): 379-399.

Freund, C. and Bolaky, B. (2008). “Trade, Regulations, and Income," Journal of Development Economics, 87: 309-321.

Fugazza, M. (2004). "Export Performance and Its Determinants: Supply and Demand Constraints," Policy Issues in International Trade and Commodities Study Series No.26, United Nations.

Gupta, S. and Yang, Y. (2006). "Unblocking Trade," Finance and Development, 43(4): $22-25$.

Hallaert, J.J. (2006). "A History of Empirical Literature on the Relationship between Trade and Growth," Mondes en Developpement, 34(3): 63-77.

Halpern, L., Koren, M., and Szeidl, A. (2015). "Imported Inputs and Productivity." The American Economic Review, 105(2): 3660-3703.

Head, K. (2003). “Gravity for Beginners,” Mimeo University of British Columbia.

Hoekman, B. and Nicita, A. (2011). "Trade Policy, Trade Costs, and Developing Country Trade," World Development, 39(12): 2069-2079.

Iwanow, T. and Kirkpatrick, C. (2009). "Trade Facilitation and Manufacturing Exports: Is Africa Different?” World Development, 37(6): 1039-1050.

Kasahara, H. and Rodrigue, J. (2008). "Does the Use of Imported Intermediates Increase Productivity? Plant Level Evidence," Journal of Development Economics, 87: 106-118.

Kaufman, D., Kraay, A., and Mastruzzi, M. (2009). “Governance Matters VIII Aggregate and Individual Governance Indicators 1996-2008," World Bank Policy Research Working Paper 4978.

Kee, H.L., Nicita, A., and Olarreag M. (2009). "Estimating Trade Restrictiveness Indices," Economic Journal, 119: 172-199.

Limao, N. and Venables, A.J. (2001). "Infrastructure, Geographical Disadvantage, Transport Costs, and Trade," The World Bank Economic Review, 15(3): 451-479. 
Morrissey, O. (2005). "Imports and Implementation: Neglected Aspects of Trade in the Report of the Commission for Africa," Journal of Development Studies, 41(4): 1133-1153.

North, D. (1990). Institutions, Institutional Change and Economic Performance. Cambridge: Cambridge University Press.

Redding, S. and Venables, A.J. (2003). "Geography and Export Performance: External Market Access and Internal Supply Capacity,” NBER Working Paper 9637, NBER.

Francisco, R. and Rodrik, D. (2000). "Trade Policy and Economic Growth: A Skeptic's Guide to the Cross-national Evidence," Macroeconomics Annual, NBER and MIT Press.

Rodrik, D. (1998). "Trade Policy and Economic Performance in Sub-Saharan Africa," NBER Working Paper, No.6562.

Rodrik, D., Subramanian, A., and Trebbi, F. (2004). "Institutional Rule: The Primacy of Institutions over Geography and Integration in Economic Development," Journal of Economic Growth, 9(2): 131-165.

Şeker, M. (2012). "Importing, Exporting, and Innovation in Developing Countries," Review of International Economics, 20(2): 299-314.

UNCTAD (2002a). World Investment Report. United Nations, Geneva.

------, (2002b). Trade and Development Report. United Nations, Geneva.

Wacziarg, R. and Welch, K.H. (2008), "Trade Liberalization and Growth: The New Evidence," The World Bank Economic Review, 22(2): 187-231.

Wilson, J.S., Mann, C.L., and Otsuki, T. (2003). "Trade Facilitation, and Economic Development: A New Approach to Quantifying the Impact," The World Bank Economic Review, 17(3): 367-389. 


\section{Tables}

Table 1

List of Countries

\begin{tabular}{|c|c|c|c|c|c|c|c|}
\hline 1 & Albania & 36 & Djibouti & 71 & Kyrgyz Republic & 106 & Russian Federation \\
\hline 2 & Algeria & 37 & Dominica & 72 & Lao PDR & 107 & Senegal \\
\hline 3 & Argentina & 38 & Dominican Rep. & 73 & Latvia & 108 & Serbia \\
\hline 4 & Armenia & 39 & Ecuador & 74 & Lebanon & 109 & Seychelles \\
\hline 5 & Australia & 40 & Egypt, Arab Rep. & 75 & Lesotho & 110 & Slovak Republic \\
\hline 6 & Austria & 41 & El Salvador & 76 & Lithuania & 111 & Slovenia \\
\hline 7 & Azerbaijan & 42 & Eritrea & 77 & Luxembourg & 112 & South Africa \\
\hline 8 & Bangladesh & 43 & Estonia & 78 & Macao, China & 113 & Spain \\
\hline 9 & Belarus & 44 & Ethiopia & 79 & Macedonia, FYR & 114 & Sudan \\
\hline 10 & Belgium & 45 & Finland & 80 & Madagascar & 115 & Swaziland \\
\hline 11 & Belize & 46 & France & 81 & Malawi & 116 & Sweden \\
\hline 12 & Benin & 47 & Gabon & 82 & Malaysia & 117 & Switzerland \\
\hline 13 & Bolivia & 48 & Gambia, The & 83 & Mali & 118 & Syrian Arab Republic \\
\hline 14 & Bosnia and Herz. & 49 & Georgia & 84 & Mauritania & 119 & Tajikistan \\
\hline 15 & Botswana & 50 & Germany & 85 & Mauritius & 120 & Tanzania \\
\hline 16 & Brazil & 51 & Ghana & 86 & Mexico & 121 & Thailand \\
\hline 17 & Brunei Darussalam & 52 & Greece & 87 & Moldova & 122 & Togo \\
\hline 18 & Bulgaria & 53 & Guatemala & 88 & Montenegro & 123 & Trinidad and Tobago \\
\hline 19 & Burkina Faso & 54 & Guinea & 89 & Morocco & 124 & Tunisia \\
\hline 20 & Cambodia & 55 & Guinea Bissau & 90 & Mozambique & 125 & Turkey \\
\hline 21 & Cameroon & 56 & Honduras & 91 & Namibia & 126 & Turkmenistan \\
\hline 22 & Canada & 57 & Hong Kong & 92 & Netherlands & 127 & Uganda \\
\hline 23 & Cape Verde & 58 & Hungary & 93 & New Zealand & 128 & Ukraine \\
\hline 24 & Central Afr. Rep. & 59 & Iceland & 94 & Nicaragua & 129 & United Kingdom \\
\hline 25 & Chad & 60 & India & 95 & North America & 130 & United States \\
\hline 26 & Chile & 61 & Indonesia & 96 & Norway & 131 & Uruguay \\
\hline 27 & China & 62 & Iran, Islamic Rep. & 97 & Pakistan & 132 & Uzbekistan \\
\hline 28 & Colombia & 63 & Ireland & 98 & Panama & 133 & Venezuela, RB \\
\hline 29 & Comoros & 64 & Israel & 99 & Papua New Guinea & 134 & Vietnam \\
\hline 30 & Congo, Dem. Rep. & 65 & Italy & 100 & Paraguay & 135 & West Bank and Gaza \\
\hline 31 & Costa Rica & 66 & Japan & 101 & Peru & 136 & Zambia \\
\hline 32 & Croatia & 67 & Jordan & 102 & Philippines & 137 & Zimbabwe \\
\hline 33 & Czech Republic & 68 & Kazakhstan & 103 & Poland & & \\
\hline 34 & Côte d'Ivoire & 69 & Kenya & 104 & Portugal & & \\
\hline 35 & Denmark & 70 & Korea, Rep. & 105 & Romania & & \\
\hline
\end{tabular}


Table 2

Regional and Income Distribution of Countries in 2005

\begin{tabular}{lcccccc}
\hline & $\begin{array}{c}\text { High } \\
\text { Income: } \\
\text { OECD }\end{array}$ & $\begin{array}{c}\text { High Income: } \\
\text { nonOECD }\end{array}$ & $\begin{array}{c}\text { Upper } \\
\text { Middle }\end{array}$ & $\begin{array}{c}\text { Lower } \\
\text { Middle }\end{array}$ & $\begin{array}{c}\text { Low } \\
\text { Income }\end{array}$ & Total \\
\hline Region & 4 & 3 & 1 & 5 & 3 & 16 \\
East Asia \& Pacific & 21 & 4 & 13 & 7 & 3 & 48 \\
Europe \& Central Asia & 2 & 1 & 12 & 8 & - & 23 \\
Latin America \& Carib. & - & - & 2 & 8 & - & 10 \\
Middle East \& North & - & - & - & 2 & 1 & 3 \\
Afr. & - & - & 6 & 6 & 24 & 36 \\
South Asia & 27 & 8 & 34 & 36 & 31 & 136 \\
Sub-Saharan Africa & & & & & & \\
\hline Total & & & & & & \\
\end{tabular}

Table 3

Variables Used in the Analysis

\begin{tabular}{|c|c|c|c|c|}
\hline Variable & Description & Years Used & Source & $\begin{array}{l}\text { Expected } \\
\text { Relation }\end{array}$ \\
\hline Real Export & Log of export in constant $2005 \$$ & $2006-2008$ & WDI & \\
\hline RealGDP(PPP) & Log of GDP, PPP (constant 2005 international \$) & $2005-2007$ & WDI & + \\
\hline Finance & Log of the ratio of M2 (money and quasi money) to GDP & $2005-2007$ & WDI & + \\
\hline FDI & Foreign direct investment, net inflows (\% of GDP) & $2005-2007$ & WDI & + \\
\hline MATTRI & Log of MA-TTRI (applied tariff incl. prefs.) - All goods & $2005-2007$ & WTI & - \\
\hline TTRI & Log of TTRI (MFN $\dagger$ applied tariff) - All goods & $2005-2007$ & WTI & - \\
\hline MAOTRI & $\begin{array}{l}\text { Log of MA-OTRI (applied tariff incl. prefs.+NTMs) - } \\
\text { All goods }\end{array}$ & $2005-2007$ & WTI & - \\
\hline OTRI & Log of OTRI (MFN applied tariff+NTMs) - All goods & $2005-2007$ & WTI & - \\
\hline Time to Exp & Log number of days to export across borders & $2005-2007$ & DB & - \\
\hline Entry & Number of procedures required to start a business & $2005-2007$ & DB & - \\
\hline Size of Trade & Size of the trade sector relative to expected & $2005-2007$ & EFW & + \\
\hline Property & Index measuring protection of property rights & $2005-2007$ & EFW & + \\
\hline Infrastructure & Log of overall quality of infrastructure & 2008 & GCR & + \\
\hline Area & Log of area in square kilometers & - & CEPII & - \\
\hline Remoteness & Weighted measure of remoteness of the country & 2008 & Author & - \\
\hline Regulatory Quality & Overall quality of the regulatory system & $2005-2007$ & WGI & + \\
\hline
\end{tabular}

Note: WDI: World Bank Development Indicators, WTI: World Trade Indicators, DB: Doing Business, GCR: Global Competitiveness Report, EFW: Economic Freedom of the World, WGI: World Governance Indicators. 
Table 4

Descriptive Statistics

\begin{tabular}{|c|c|c|c|c|c|c|c|c|c|c|c|c|c|}
\hline Variable & & Mean & $\begin{array}{l}\text { Std. } \\
\text { Dev }\end{array}$ & Min & Max & Obs. & Variable & & Mean & Std. Dev & Min & Max & Obs. \\
\hline \multirow{3}{*}{ Real Export } & overall & 23.3 & 2.18 & 17.6 & 28.0 & $\mathrm{~N}=339$ & \multirow{3}{*}{ Regulation } & overall & -0.02 & 1.01 & -2.7 & 1.9 & $\begin{array}{l}\mathrm{N}= \\
592\end{array}$ \\
\hline & between & & 2.30 & 17.7 & 28.0 & $\mathrm{n}=131$ & & between & & 1.00 & -2.6 & 1.9 & $\mathrm{n}=198$ \\
\hline & within & & 0.08 & 22.8 & 23.5 & $\mathrm{~T}=2.6$ & & within & & 0.09 & -0.4 & 0.4 & $\mathrm{~T}=3$ \\
\hline \multirow{3}{*}{$\begin{array}{l}\text { Real } \\
\text { GDP(PPP) }\end{array}$} & overall & 24.3 & 2.27 & 19.2 & 30.2 & $\mathrm{~N}=531$ & \multirow{3}{*}{ Finance } & overall & 3.7 & 0.69 & 1.7 & 5.6 & $\begin{array}{l}\mathrm{N}= \\
476\end{array}$ \\
\hline & between & & 2.26 & 19.2 & 30.2 & $\mathrm{n}=180$ & & between & & 0.69 & 1.8 & 5.6 & $\mathrm{n}=164$ \\
\hline & within & & 0.05 & 24.0 & 24.6 & $\mathrm{~T}=3$ & & within & & 0.08 & 3.2 & 4.2 & $\mathrm{~T}=3$ \\
\hline \multirow{3}{*}{ Area } & overall & 11.2 & 2.73 & 3.2 & 16.7 & $\mathrm{~N}=594$ & \multirow{3}{*}{ Entry } & overall & 9.4 & 3.43 & 2.0 & 20.0 & $\begin{array}{l}\mathrm{N}= \\
528\end{array}$ \\
\hline & between & & 2.74 & 3.2 & 16.7 & $\mathrm{n}=198$ & & between & & 3.37 & 2.0 & 20.0 & $\mathrm{n}=179$ \\
\hline & within & & 0 & 11.2 & 11.2 & $\mathrm{~T}=3$ & & within & & 0.73 & 2.7 & 12.7 & $\mathrm{~T}=3$ \\
\hline \multirow{3}{*}{ Remote } & overall & 9.0 & 0.26 & 8.6 & 9.7 & $\mathrm{~N}=507$ & \multirow{3}{*}{$\begin{array}{l}\text { Time to } \\
\text { Exp }\end{array}$} & overall & 3.1 & 0.62 & 1.6 & 4.6 & $\begin{array}{l}\mathrm{N}= \\
509\end{array}$ \\
\hline & between & & 0.26 & 8.6 & 9.7 & $\mathrm{n}=169$ & & between & & 0.60 & 1.6 & 4.6 & $\mathrm{n}=179$ \\
\hline & within & & 0 & 9.0 & 9.0 & $\mathrm{~T}=3$ & & within & & 0.13 & 2.6 & 4.1 & $\mathrm{~T}=2.8$ \\
\hline \multirow{3}{*}{$\begin{array}{l}\text { Export } \\
\text { Growth }_{\mathrm{t}-1, \mathrm{t}-2}\end{array}$} & overall & 2.0 & 0.83 & -1.7 & 4.8 & $\mathrm{~N}=338$ & \multirow{3}{*}{$\begin{array}{l}\text { Infra- } \\
\text { structure }\end{array}$} & overall & 1.3 & 0.37 & 0.4 & 1.9 & $\begin{array}{l}\mathrm{N}= \\
399\end{array}$ \\
\hline & between & & 0.66 & 0.1 & 3.8 & $\mathrm{n}=134$ & & between & & 0.37 & 0.4 & 1.9 & $\mathrm{n}=133$ \\
\hline & within & & 0.53 & -0.5 & 4.1 & $\mathrm{~T}=2.5$ & & within & & 0 & 1.3 & 1.3 & $\mathrm{~T}=3$ \\
\hline \multirow{3}{*}{ TTRI } & overall & 1.8 & 0.66 & -3.3 & 3.4 & $\mathrm{~N}=325$ & \multirow{3}{*}{ Property } & overall & 6.1 & 1.82 & 1.4 & 9.6 & $\begin{array}{l}N= \\
368\end{array}$ \\
\hline & between & & 0.74 & -3.3 & 3.2 & $\mathrm{n}=126$ & & between & & 1.80 & 1.7 & 9.4 & $\mathrm{n}=125$ \\
\hline & within & & 0.14 & 0.9 & 2.5 & $\mathrm{~T}=2.6$ & & within & & 0.26 & 5.0 & 7.0 & $\mathrm{~T}=2.9$ \\
\hline \multirow{3}{*}{ MATTRI } & overall & 1.2 & 0.82 & -2.3 & 3.3 & $\mathrm{~N}=345$ & & & & & & & \\
\hline & between & & 0.71 & -0.9 & 2.9 & $\mathrm{n}=127$ & & & & & & & \\
\hline & within & & 0.44 & -0.2 & 3.4 & $\mathrm{~T}=2.7$ & & & & & & & \\
\hline
\end{tabular}


Table 5

Correlation Matrix

\begin{tabular}{|c|c|c|c|c|c|c|c|c|c|c|c|c|}
\hline & $\begin{array}{l}\text { Real } \\
\text { Export }\end{array}$ & $\begin{array}{l}\text { RealGDP } \\
(\mathrm{PPP})\end{array}$ & (MATTRI & TTRI & Area & Remote & $\begin{array}{l}\operatorname{Exp} \\
\mathrm{Gr}^{\mathrm{r}-1,1,-2-2} \\
\end{array}$ & Regul. & Finance & Entry & $\begin{array}{l}\text { Time } \\
\text { to Exp }\end{array}$ & Infrast \\
\hline RealGDP(PPP) & 0.95 & & & & & & & & & & & \\
\hline MATTRI & 0.1 & 0.03 & & & & & & & & & & \\
\hline TTRI & -0.32 & -0.24 & 0.02 & & & & & & & & & \\
\hline Area & 0.32 & 0.61 & -0.15 & 0.29 & & & & & & & & \\
\hline Remoteness & -0.25 & -0.31 & -0.06 & 0.21 & -0.09 & & & & & & & \\
\hline Export $\mathrm{Gr}_{\mathrm{t}-1, \mathrm{t}-2}$ & -0.02 & -0.09 & 0.04 & 0.03 & -0.06 & 0 & & & & & & \\
\hline Regulations & 0.58 & 0.39 & 0.16 & -0.58 & -0.26 & -0.33 & -0.12 & & & & & \\
\hline Finance & 0.39 & 0.13 & 0.11 & -0.41 & -0.36 & -0.05 & 0 & 0.59 & & & & \\
\hline Entry & -0.27 & -0.05 & -0.11 & 0.35 & 0.25 & 0.12 & 0.09 & -0.49 & -0.43 & & & \\
\hline Time to Exp & -0.57 & -0.4 & -0.09 & 0.5 & 0.19 & 0.27 & 0.15 & -0.78 & -0.57 & 0.42 & & \\
\hline Infrastructure & 0.55 & 0.43 & 0.02 & -0.49 & -0.28 & -0.28 & -0.18 & 0.78 & 0.61 & -0.46 & -0.69 & \\
\hline Property & 0.53 & 0.39 & 0.12 & -0.46 & -0.26 & -0.24 & -0.16 & 0.87 & 0.63 & -0.58 & -0.74 & 0.85 \\
\hline
\end{tabular}

* Bold cells show significance levels with $\mathrm{p}>0.05$. The rest is significant at 1 percent. 
Table 6

Export Performance and Investment Climate

\begin{tabular}{|c|c|c|c|c|c|c|}
\hline & Regulations & Finance & Entry & $\begin{array}{l}\text { Time to } \\
\text { Exp }\end{array}$ & Infrastructure & Property \\
\hline RealGDP(PPP) & $\begin{array}{l}0.989 \\
(0.031)^{* * *}\end{array}$ & $\begin{array}{l}1.006 \\
(0.045)^{* * *}\end{array}$ & $\begin{array}{l}1.064 \\
(0.034)^{* * *}\end{array}$ & $\begin{array}{l}0.976 \\
(0.032)^{* * *}\end{array}$ & $\begin{array}{l}0.978 \\
(0.030)^{* * *}\end{array}$ & $\begin{array}{l}0.994 \\
(0.034)^{* * *}\end{array}$ \\
\hline Area & $\begin{array}{l}-0.082 \\
(0.035)^{* *}\end{array}$ & $\begin{array}{l}-0.081 \\
(0.043)^{*}\end{array}$ & $\begin{array}{l}-0.129 \\
(0.043)^{* * *}\end{array}$ & $\begin{array}{l}-0.060 \\
(0.037)\end{array}$ & $\begin{array}{l}-0.079 \\
(0.040)^{* *}\end{array}$ & $\begin{array}{l}-0.091 \\
(0.041)^{* *}\end{array}$ \\
\hline Remoteness & $\begin{array}{l}-0.384 \\
(0.155)^{* *}\end{array}$ & $\begin{array}{l}-0.470 \\
(0.188)^{* *}\end{array}$ & $\begin{array}{l}-0.422 \\
(0.182)^{* *}\end{array}$ & $\begin{array}{l}-0.474 \\
(0.157)^{* * *}\end{array}$ & $\begin{array}{l}-0.504 \\
(0.163)^{* * *}\end{array}$ & $\begin{array}{l}-0.533 \\
(0.175)^{* * *}\end{array}$ \\
\hline Export Growth $_{\mathrm{t}, \mathrm{t}-1}$ & $\begin{array}{l}0.094 \\
(0.046)^{* *}\end{array}$ & $\begin{array}{l}0.094 \\
(0.060)\end{array}$ & $\begin{array}{l}0.077 \\
(0.049)\end{array}$ & $\begin{array}{l}0.101 \\
(0.047)^{* *}\end{array}$ & $\begin{array}{l}0.134 \\
(0.048)^{* * *}\end{array}$ & $\begin{array}{l}0.121 \\
(0.047)^{* *}\end{array}$ \\
\hline TTRI & $\begin{array}{l}-0.265 \\
(0.094)^{* * *}\end{array}$ & $\begin{array}{l}-0.498 \\
(0.111)^{* * *}\end{array}$ & $\begin{array}{l}-0.458 \\
(0.109)^{* * *}\end{array}$ & $\begin{array}{l}-0.432 \\
(0.085)^{* * *}\end{array}$ & $\begin{array}{l}-0.397 \\
(0.084)^{* * *}\end{array}$ & $\begin{array}{l}-0.411 \\
(0.096)^{* * *}\end{array}$ \\
\hline MATTRI & $\begin{array}{l}-0.185 \\
(0.046)^{* * *}\end{array}$ & $\begin{array}{l}-0.805 \\
(0.318)^{* *}\end{array}$ & $\begin{array}{l}0.202 \\
(0.131)\end{array}$ & $\begin{array}{l}0.269 \\
(0.257)\end{array}$ & $\begin{array}{l}-0.526 \\
(0.170)^{* * *}\end{array}$ & $\begin{array}{l}-0.536 \\
(0.167)^{* * *}\end{array}$ \\
\hline MATTRI*Indicator & $\begin{array}{l}0.124 \\
(0.055)^{* *}\end{array}$ & $\begin{array}{l}0.173 \\
(0.089)^{*}\end{array}$ & $\begin{array}{l}-0.037 \\
(0.011)^{* * *}\end{array}$ & $\begin{array}{l}-0.141 \\
(0.077)^{*}\end{array}$ & $\begin{array}{l}0.299 \\
(0.117)^{* *}\end{array}$ & $\begin{array}{l}0.058 \\
(0.025)^{* *}\end{array}$ \\
\hline Indicator & $\begin{array}{l}0.281 \\
(0.076)^{* * *}\end{array}$ & $\begin{array}{l}-0.028 \\
(0.139)\end{array}$ & $\begin{array}{l}0.004 \\
(0.021)\end{array}$ & $\begin{array}{l}-0.345 \\
(0.134)^{* *}\end{array}$ & $\begin{array}{l}0.599 \\
(0.195)^{* * *}\end{array}$ & $\begin{array}{l}0.114 \\
(0.039)^{* * *}\end{array}$ \\
\hline Constant & $\begin{array}{l}3.493 \\
(1.612)^{* *}\end{array}$ & $\begin{array}{l}4.357 \\
(1.959)^{* *}\end{array}$ & $\begin{array}{l}2.915 \\
(1.843) \\
\end{array}$ & $\begin{array}{l}5.761 \\
(1.671)^{* * *}\end{array}$ & $\begin{array}{l}4.321 \\
(1.591)^{* * *}\end{array}$ & $\begin{array}{l}4.457 \\
(1.833)^{* *}\end{array}$ \\
\hline Observations & 205 & 175 & 204 & 203 & 193 & 189 \\
\hline R-squared & 0.953 & 0.933 & 0.944 & 0.952 & 0.954 & 0.954 \\
\hline
\end{tabular}

* Estimation results with pooled OLS method. Robust standard errors clustered by country are in parentheses. All regressions control for year fixed effects. $* * * \mathrm{p}<0.01, * * \mathrm{p}<0.05, * \mathrm{p}<0.1$.

Table 7

Impacts of Improvements in Investment Climate Indicators on Exports (in percentage points)

\begin{tabular}{|c|c|c|c|c|c|c|}
\hline Indicator & Regulations & Finance & Entry & Time to Exp & Infrastructure & Property \\
\hline Total Impact & 10.1 & 9.9 & 12.4 & 7.9 & 10 & 9.6 \\
\hline
\end{tabular}


Table 8

Impacts of One Standard Deviation Decrease in Market Access on Exports (in percentage points)

\begin{tabular}{lcccccc}
\hline Indicator & Regulations & Finance & Entry & Time to Exp & Infrastructure & Property \\
\hline Total Impact & 13.5 & 10.3 & -16.1 & -7 & 15.1 & 12.3 \\
\hline Note: One standard deviation decrease in market access means increase in the tariff rates (MATTRI). Recall from \\
Table 3 that larger values of regulatory quality, access to finance, quality of infrastructure, and protection of \\
property rights lead to more export revenues and larger values of number of entry procedures and number of days to \\
export means decrease in trade.
\end{tabular}

Table 9

Estimation Results with Alternative Indicators for Investment Climate

\begin{tabular}{|c|c|c|c|c|}
\hline & Rule of Law & LPI & Property(IEF) & Power Outage \\
\hline \multirow[t]{2}{*}{ RealGDP(PPP) } & 0.993 & 0.870 & 1.017 & 1.009 \\
\hline & $(0.031)^{* * *}$ & $(0.037)^{* * *}$ & $(0.032)^{* * *}$ & $(0.037)^{* * *}$ \\
\hline \multirow[t]{2}{*}{ Area } & -0.087 & -0.072 & -0.095 & -0.095 \\
\hline & $(0.038)^{* *}$ & $(0.034)^{* *}$ & $(0.039)^{* *}$ & $(0.033)^{* * *}$ \\
\hline \multirow[t]{2}{*}{ Remoteness } & -0.419 & -0.482 & -0.593 & -0.364 \\
\hline & $(0.158)^{* * *}$ & $(0.159)^{* * *}$ & $(0.166)^{* * *}$ & $(0.169)^{* *}$ \\
\hline \multirow[t]{2}{*}{ Export Growth $_{\mathrm{t}, \mathrm{-}-1}$} & 0.106 & 0.131 & 0.104 & 0.104 \\
\hline & $(0.046)^{* *}$ & $(0.040)^{* * *}$ & $(0.048)^{* *}$ & $(0.043)^{* *}$ \\
\hline \multirow[t]{2}{*}{ TTRI } & -0.309 & -0.330 & -0.358 & -0.297 \\
\hline & $(0.091)^{* * *}$ & $(0.092)^{* * *}$ & $(0.097)^{* * *}$ & $(0.110)^{* * *}$ \\
\hline \multirow[t]{2}{*}{ MATTRI } & -0.164 & -0.218 & -0.766 & -0.049 \\
\hline & $(0.043)^{* * *}$ & $(0.049)^{* * *}$ & $(0.348)^{* *}$ & $(0.068)$ \\
\hline \multirow[t]{2}{*}{ MATTRI*Indicator } & 0.067 & 0.121 & 0.157 & -0.093 \\
\hline & $(0.039)^{*}$ & $(0.056)^{* *}$ & $(0.085)^{*}$ & $(0.052)^{*}$ \\
\hline \multirow[t]{2}{*}{ Indicator } & 0.292 & 0.376 & 0.505 & -0.279 \\
\hline & $(0.054)^{* * *}$ & $(0.107)^{* * *}$ & $(0.110)^{* * *}$ & $(0.071)^{* * *}$ \\
\hline \multirow[t]{2}{*}{ Constant } & 3.910 & 7.399 & 3.187 & 3.343 \\
\hline & $(1.578)^{* *}$ & $(1.438)^{* * *}$ & $(1.674)^{*}$ & $(1.857)^{*}$ \\
\hline Observations & 205 & 198 & 202 & 110 \\
\hline R-squared & 0.954 & 0.959 & 0.950 & 0.960 \\
\hline
\end{tabular}


Table 10

Population-averaged Estimator with Autoregressive Error Term

\begin{tabular}{|c|c|c|c|c|c|}
\hline & Regulations & Finance & Entry & Time to Exp & Property \\
\hline RealGDP(PPP) & $\begin{array}{l}1.071 \\
(0.039)^{* * *}\end{array}$ & $\begin{array}{l}1.080 \\
(0.047)^{* * *}\end{array}$ & $\begin{array}{l}1.138 \\
(0.037)^{* * *}\end{array}$ & $\begin{array}{l}1.138 \\
(0.038)^{* * *}\end{array}$ & $\begin{array}{l}1.093 \\
(0.043)^{* * *}\end{array}$ \\
\hline Area & $\begin{array}{l}-0.166 \\
(0.043)^{* * *}\end{array}$ & $\begin{array}{l}-0.168 \\
(0.044)^{* * *}\end{array}$ & $\begin{array}{l}-0.210 \\
(0.041)^{* * *}\end{array}$ & $\begin{array}{l}-0.213 \\
(0.041)^{* * *}\end{array}$ & $\begin{array}{l}-0.201 \\
(0.051)^{* * *}\end{array}$ \\
\hline Remoteness & $\begin{array}{l}-0.458 \\
(0.183)^{* *}\end{array}$ & $\begin{array}{l}-0.439 \\
(0.221)^{* *}\end{array}$ & $\begin{array}{l}-0.521 \\
(0.218)^{* *}\end{array}$ & $\begin{array}{l}-0.577 \\
(0.228)^{* *}\end{array}$ & $\begin{array}{l}-0.583 \\
(0.221)^{* * *}\end{array}$ \\
\hline Export Growth $_{\mathrm{t}, \mathrm{t}-1}$ & $\begin{array}{l}0.023 \\
(0.018)\end{array}$ & $\begin{array}{l}0.027 \\
(0.021)\end{array}$ & $\begin{array}{l}0.018 \\
(0.018)\end{array}$ & $\begin{array}{l}0.022 \\
(0.018)\end{array}$ & $\begin{array}{l}0.026 \\
(0.020)\end{array}$ \\
\hline TTRI & $\begin{array}{l}-0.050 \\
(0.030)^{*}\end{array}$ & $\begin{array}{l}-0.092 \\
(0.043)^{* *}\end{array}$ & $\begin{array}{l}-0.073 \\
(0.031)^{* *}\end{array}$ & $\begin{array}{l}-0.062 \\
(0.028)^{* *}\end{array}$ & $\begin{array}{l}-0.090 \\
(0.038)^{* *}\end{array}$ \\
\hline MATTRI & $\begin{array}{l}-0.022 \\
(0.012)^{*}\end{array}$ & $\begin{array}{l}-0.143 \\
(0.069)^{* *}\end{array}$ & $\begin{array}{l}0.023 \\
(0.024)\end{array}$ & $\begin{array}{l}0.132 \\
(0.058)^{* *}\end{array}$ & $\begin{array}{l}-0.113 \\
(0.054)^{* *}\end{array}$ \\
\hline MATTRI*Indicator & $\begin{array}{l}0.033 \\
(0.015)^{* *}\end{array}$ & $\begin{array}{l}0.032 \\
(0.018)^{*}\end{array}$ & $\begin{array}{l}-0.005 \\
(0.002)^{* *}\end{array}$ & $\begin{array}{l}-0.047 \\
(0.018)^{* * *}\end{array}$ & $\begin{array}{l}0.015 \\
(0.008)^{*}\end{array}$ \\
\hline Indicator & $\begin{array}{l}0.235 \\
(0.073)^{* * *}\end{array}$ & $\begin{array}{l}0.156 \\
(0.091)^{*}\end{array}$ & $\begin{array}{l}-0.007 \\
(0.004)^{* *}\end{array}$ & $\begin{array}{l}0.062 \\
(0.041)\end{array}$ & $\begin{array}{l}0.034 \\
(0.032)\end{array}$ \\
\hline Constant & $\begin{array}{l}2.833 \\
(1.869)\end{array}$ & $\begin{array}{l}1.954 \\
(2.172)\end{array}$ & $\begin{array}{l}2.417 \\
(2.225) \\
\end{array}$ & $\begin{array}{l}2.667 \\
(2.374) \\
\end{array}$ & $\begin{array}{l}3.776 \\
(2.330)\end{array}$ \\
\hline $\begin{array}{l}\text { Observations } \\
\text { Prob }>\text { Chi2 }\end{array}$ & $\begin{array}{l}179 \\
0.000\end{array}$ & $\begin{array}{l}151 \\
0.000\end{array}$ & $\begin{array}{l}177 \\
0.000\end{array}$ & $\begin{array}{l}177 \\
0.000\end{array}$ & $\begin{array}{l}169 \\
0.000\end{array}$ \\
\hline
\end{tabular}


Table 11

Random Effects Estimator with Autoregressive Error Term

\begin{tabular}{|c|c|c|c|c|c|c|}
\hline & Regulations & Finance & Entry & $\begin{array}{l}\text { Time to } \\
\text { Exp }\end{array}$ & Infrastructure & Property \\
\hline RealGDP(PPP) & $\begin{array}{l}1.007 \\
(0.029)^{* * *}\end{array}$ & $\begin{array}{l}1.044 \\
(0.039)^{* * *}\end{array}$ & $\begin{array}{l}1.088 \\
(0.029)^{* * *}\end{array}$ & $\begin{array}{l}1.035 \\
(0.030)^{* * *}\end{array}$ & $\begin{array}{l}0.984 \\
(0.029)^{* * *}\end{array}$ & $\begin{array}{l}1.031 \\
(0.029)^{* * *}\end{array}$ \\
\hline Area & $\begin{array}{l}-0.123 \\
(0.031)^{* * *}\end{array}$ & $\begin{array}{l}-0.139 \\
(0.037)^{* * *}\end{array}$ & $\begin{array}{l}-0.185 \\
(0.032)^{* * *}\end{array}$ & $\begin{array}{l}-0.133 \\
(0.031)^{* * *}\end{array}$ & $\begin{array}{l}-0.108 \\
(0.030)^{* * *}\end{array}$ & $\begin{array}{l}-0.137 \\
(0.031)^{* * *}\end{array}$ \\
\hline Remoteness & $\begin{array}{l}-0.408 \\
(0.161)^{* *}\end{array}$ & $\begin{array}{l}-0.408 \\
(0.184)^{* *}\end{array}$ & $\begin{array}{l}-0.491 \\
(0.177)^{* * *}\end{array}$ & $\begin{array}{l}-0.573 \\
(0.164)^{* * *}\end{array}$ & $\begin{array}{l}-0.542 \\
(0.154)^{* * *}\end{array}$ & $\begin{array}{l}-0.582 \\
(0.160)^{* * *}\end{array}$ \\
\hline Export Growth $_{\mathrm{t}, \mathrm{t}-1}$ & $\begin{array}{l}0.034 \\
(0.016)^{* *}\end{array}$ & $\begin{array}{l}0.038 \\
(0.019)^{* *}\end{array}$ & $\begin{array}{l}0.026 \\
(0.016)\end{array}$ & $\begin{array}{l}0.034 \\
(0.019)^{*}\end{array}$ & $\begin{array}{l}0.042 \\
(0.016)^{* *}\end{array}$ & $\begin{array}{l}0.045 \\
(0.019)^{* *}\end{array}$ \\
\hline TTRI & $\begin{array}{l}-0.104 \\
(0.052)^{* *}\end{array}$ & $\begin{array}{l}-0.195 \\
(0.057)^{* * *}\end{array}$ & $\begin{array}{l}-0.203 \\
(0.053)^{* * *}\end{array}$ & $\begin{array}{l}-0.216 \\
(0.058)^{* * *}\end{array}$ & $\begin{array}{l}-0.162 \\
(0.050)^{* * *}\end{array}$ & $\begin{array}{l}-0.220 \\
(0.055)^{* * *}\end{array}$ \\
\hline MATTRI & $\begin{array}{l}-0.044 \\
(0.022)^{* *}\end{array}$ & $\begin{array}{l}-0.170 \\
(0.130)\end{array}$ & $\begin{array}{l}0.060 \\
(0.063)\end{array}$ & $\begin{array}{l}0.174 \\
(0.152)\end{array}$ & $\begin{array}{l}-0.145 \\
(0.067)^{* *}\end{array}$ & $\begin{array}{l}-0.202 \\
(0.076)^{* * *}\end{array}$ \\
\hline MATTRI*Indicator & $\begin{array}{l}0.049 \\
(0.025)^{* *}\end{array}$ & $\begin{array}{l}0.031 \\
(0.036)\end{array}$ & $\begin{array}{l}-0.011 \\
(0.006)^{*}\end{array}$ & $\begin{array}{l}-0.074 \\
(0.045)^{*}\end{array}$ & $\begin{array}{l}0.077 \\
(0.051)\end{array}$ & $\begin{array}{l}0.023 \\
(0.012)^{*}\end{array}$ \\
\hline Indicator & $\begin{array}{l}0.310 \\
(0.060)^{* * *}\end{array}$ & $\begin{array}{l}0.115 \\
(0.092)\end{array}$ & $\begin{array}{l}-0.018 \\
(0.010)^{*}\end{array}$ & $\begin{array}{l}-0.214 \\
(0.089)^{* *}\end{array}$ & $\begin{array}{l}0.938 \\
(0.144)^{* * *}\end{array}$ & $\begin{array}{l}0.110 \\
(0.027)^{* * *}\end{array}$ \\
\hline Constant & $\begin{array}{l}3.562 \\
(1.585)^{* *}\end{array}$ & $\begin{array}{l}2.579 \\
(1.816) \\
\end{array}$ & $\begin{array}{l}3.489 \\
(1.746)^{* *}\end{array}$ & $\begin{array}{l}5.342 \\
(1.638)^{* * *}\end{array}$ & $\begin{array}{l}4.162 \\
(1.521)^{* * *}\end{array}$ & $\begin{array}{l}4.282 \\
(1.579)^{* * *}\end{array}$ \\
\hline Observations & 205 & 175 & 204 & 203 & 193 & 189 \\
\hline R-Squared & 0.947 & 0.921 & 0.935 & 0.943 & 0.947 & 0.946 \\
\hline Prob $>$ Chi 2 & 0.000 & 0.000 & 0.000 & 0.000 & 0.000 & 0.000 \\
\hline
\end{tabular}


Table 12

Controlling Size of Trade Market and FDI

\begin{tabular}{|c|c|c|c|c|c|c|}
\hline & Regulations & Finance & Entry & $\begin{array}{l}\text { Time to } \\
\text { Exp }\end{array}$ & Infrastructure & Property \\
\hline RealGDP(PPP) & $\begin{array}{l}0.977 \\
(0.026)^{* * *}\end{array}$ & $\begin{array}{l}1.005 \\
(0.041)^{* * *}\end{array}$ & $\begin{array}{l}1.063 \\
(0.033)^{* * *}\end{array}$ & $\begin{array}{l}0.974 \\
(0.032)^{* * *}\end{array}$ & $\begin{array}{l}0.983 \\
(0.030)^{* * *}\end{array}$ & $\begin{array}{l}0.991 \\
(0.029)^{* * *}\end{array}$ \\
\hline TTRI & $\begin{array}{l}-0.188 \\
(0.080)^{* *}\end{array}$ & $\begin{array}{l}-0.432 \\
(0.110)^{* * *}\end{array}$ & $\begin{array}{l}-0.404 \\
(0.109)^{* * *}\end{array}$ & $\begin{array}{l}-0.373 \\
(0.080)^{* * *}\end{array}$ & $\begin{array}{l}-0.374 \\
(0.088)^{* * *}\end{array}$ & $\begin{array}{l}-0.374 \\
(0.099)^{* * *}\end{array}$ \\
\hline MATTRI & $\begin{array}{l}-0.172 \\
(0.036)^{* * *}\end{array}$ & $\begin{array}{l}-1.103 \\
(0.300)^{* * *}\end{array}$ & $\begin{array}{l}0.194 \\
(0.143)\end{array}$ & $\begin{array}{l}0.495 \\
(0.287)^{*}\end{array}$ & $\begin{array}{l}-0.445 \\
(0.146)^{* * *}\end{array}$ & $\begin{array}{l}-0.482 \\
(0.144)^{* * *}\end{array}$ \\
\hline MATTRI*Indicator & $\begin{array}{l}0.154 \\
(0.052)^{* * *}\end{array}$ & $\begin{array}{l}0.251 \\
(0.085)^{* * *}\end{array}$ & $\begin{array}{l}-0.036 \\
(0.013)^{* * *}\end{array}$ & $\begin{array}{l}-0.212 \\
(0.086)^{* *}\end{array}$ & $\begin{array}{l}0.254 \\
(0.109)^{* *}\end{array}$ & $\begin{array}{l}0.056 \\
(0.023)^{* *}\end{array}$ \\
\hline Indicator & $\begin{array}{l}0.312 \\
(0.086)^{* * *}\end{array}$ & $\begin{array}{l}-0.071 \\
(0.127)\end{array}$ & $\begin{array}{l}-0.001 \\
(0.023)\end{array}$ & $\begin{array}{l}-0.275 \\
(0.151)^{*}\end{array}$ & $\begin{array}{l}0.611 \\
(0.162)^{* * *}\end{array}$ & $\begin{array}{l}0.116 \\
(0.033)^{* * *}\end{array}$ \\
\hline Size of Trade & $\begin{array}{l}0.118 \\
(0.015)^{* * *}\end{array}$ & $\begin{array}{l}0.079 \\
(0.024)^{* * *}\end{array}$ & $\begin{array}{l}0.093 \\
(0.019)^{* * *}\end{array}$ & $\begin{array}{l}0.105 \\
(0.017)^{* * *}\end{array}$ & $\begin{array}{l}0.099 \\
(0.015)^{* * *}\end{array}$ & $\begin{array}{l}0.105 \\
(0.015)^{* * *}\end{array}$ \\
\hline FDI & $\begin{array}{l}0.002 \\
(0.000)^{* * *}\end{array}$ & $\begin{array}{l}0.009 \\
(0.008)\end{array}$ & $\begin{array}{l}0.003 \\
(0.001)^{* * *}\end{array}$ & $\begin{array}{l}0.002 \\
(0.001)^{* * *}\end{array}$ & $\begin{array}{l}0.003 \\
(0.000)^{* * *}\end{array}$ & $\begin{array}{l}0.003 \\
(0.000)^{* * *}\end{array}$ \\
\hline Observations & 196 & 167 & 195 & 195 & 192 & 189 \\
\hline R-squared & 0.972 & 0.950 & 0.958 & 0.967 & 0.967 & 0.968 \\
\hline
\end{tabular}


Table 13

Estimation Results with Two Period Lags

\begin{tabular}{|c|c|c|c|c|c|c|}
\hline & Regulations & Finance & Entry & Time to Exp & Infrastructure & Property \\
\hline \multirow[t]{2}{*}{ RealGDP(PPP) } & 0.981 & 1.030 & 1.067 & 0.999 & 0.988 & 0.987 \\
\hline & $(0.031)^{* * *}$ & $(0.043)^{* * *}$ & $(0.038)^{* * *}$ & $(0.035)^{* * *}$ & $(0.035)^{* * *}$ & $(0.034)^{* * *}$ \\
\hline \multirow[t]{2}{*}{ TTRI } & -0.190 & -0.410 & -0.397 & -0.343 & -0.346 & -0.345 \\
\hline & $(0.093)^{* *}$ & $(0.124)^{* * * *}$ & $(0.114)^{* * *}$ & $(0.098)^{* * *}$ & $(0.096)^{* * *}$ & $(0.113)^{* * *}$ \\
\hline \multirow[t]{2}{*}{ MATTRI } & -0.136 & -1.120 & 0.215 & 0.596 & -0.515 & -0.559 \\
\hline & $(0.044)^{* * *}$ & $(0.326)^{* * *}$ & $(0.189)$ & $(0.341)^{*}$ & $(0.188)^{* * *}$ & $(0.183)^{* * *}$ \\
\hline \multirow[t]{2}{*}{ MATTRI*Indicator } & 0.165 & 0.266 & -0.038 & -0.238 & 0.303 & 0.071 \\
\hline & $(0.054)^{* * *}$ & $(0.095)^{* * * *}$ & $(0.016)^{* *}$ & $(0.101)^{* *}$ & $(0.146)^{* *}$ & $(0.032)^{* *}$ \\
\hline \multirow[t]{2}{*}{ Indicator } & 0.238 & -0.262 & 0.012 & -0.147 & 0.446 & 0.070 \\
\hline & $(0.080)^{* * *}$ & $(0.145)^{*}$ & $(0.029)$ & $(0.163)$ & $(0.231)^{*}$ & $(0.043)$ \\
\hline Observations & 120 & 107 & 119 & 119 & 118 & 115 \\
\hline R-squared & 0.972 & 0.950 & 0.959 & 0.966 & 0.967 & 0.966 \\
\hline
\end{tabular}

Table 14

Results for Countries with more than Median Number of Free Trade Agreements

\begin{tabular}{|c|c|c|c|c|c|c|}
\hline & Regulations & Finance & Entry & $\begin{array}{l}\text { Time to } \\
\text { Exp }\end{array}$ & Infrastructure & Property \\
\hline \multirow[t]{2}{*}{ RealGDP(PPP) } & 1.000 & 1.048 & 1.104 & 1.010 & 1.009 & 1.011 \\
\hline & $(0.026)^{* * *}$ & $(0.048)^{* * *}$ & $(0.033)^{* * *}$ & $(0.034)^{* * *}$ & $(0.028)^{* * *}$ & $(0.028) * * *$ \\
\hline \multirow[t]{2}{*}{ TTRI } & -0.166 & -0.425 & -0.385 & -0.337 & -0.340 & -0.352 \\
\hline & $(0.082)^{* *}$ & $(0.114)^{* * *}$ & $(0.104)^{* * *}$ & $(0.083)^{* * *}$ & $(0.084)^{* * *}$ & $(0.098) * * *$ \\
\hline \multirow[t]{2}{*}{ MATTRI } & -0.143 & -0.902 & 0.112 & 0.631 & -0.497 & -0.509 \\
\hline & $(0.046)^{* * *}$ & $(0.362)^{* *}$ & $(0.136)$ & $(0.257)^{* *}$ & $(0.132)^{* * *}$ & $(0.146)^{* * *}$ \\
\hline \multirow[t]{2}{*}{ MATTRI*Indicator } & 0.170 & 0.197 & -0.026 & -0.250 & 0.301 & 0.061 \\
\hline & $(0.051)^{* * *}$ & $(0.103)^{*}$ & $(0.012)^{* *}$ & $(0.077)^{* * *}$ & $(0.102)^{* * *}$ & $(0.024)^{* *}$ \\
\hline \multirow[t]{2}{*}{ Indicator } & 0.258 & -0.035 & -0.014 & -0.189 & 0.494 & 0.095 \\
\hline & $(0.078)^{* * *}$ & $(0.131)$ & $(0.017)$ & $(0.111)^{*}$ & $(0.151)^{* * *}$ & $(0.034) * * *$ \\
\hline Observations & 168 & 141 & 167 & 167 & 168 & 166 \\
\hline R-squared & 0.973 & 0.947 & 0.958 & 0.967 & 0.969 & 0.969 \\
\hline
\end{tabular}


Table 15

Results for Upper-middle and High Income Countries

\begin{tabular}{lllllll}
\hline & & & & \\
& & & & \\
& Regulations & Finance & Entry & Exp & Infrastructure & Property \\
\hline RealGDP(PPP) & 0.977 & 0.896 & 1.041 & 0.974 & 0.966 & 0.955 \\
& $(0.033)^{* * *}$ & $(0.044)^{* * *}$ & $(0.036)^{* * *}$ & $(0.041)^{* * *}$ & $(0.031)^{* * *}$ & $(0.029)^{* * *}$ \\
TTRI & -0.049 & -0.090 & -0.147 & -0.227 & -0.066 & -0.053 \\
& $(0.103)$ & $(0.122)$ & $(0.172)$ & $(0.117)^{*}$ & $(0.121)$ & $(0.122)$ \\
MATTRI & -0.154 & -0.965 & 0.234 & 0.552 & -0.147 & -0.470 \\
& $(0.058)^{* *}$ & $(0.419)^{* *}$ & $(0.131)^{*}$ & $(0.248)^{* *}$ & $(0.182)$ & $(0.233)^{* *}$ \\
MATTRI*Indicator & 0.196 & 0.254 & -0.030 & -0.203 & 0.123 & 0.070 \\
& $(0.071)^{* * *}$ & $(0.116)^{* *}$ & $(0.014)^{* *}$ & $(0.073)^{* * *}$ & $(0.142)$ & $(0.035)^{* *}$ \\
Indicator & 0.241 & 0.237 & -0.012 & -0.187 & 0.794 & 0.106 \\
& $(0.092)^{* *}$ & $(0.156)$ & $(0.025)$ & $(0.115)$ & $(0.207)^{* * *}$ & $(0.044)^{* *}$ \\
\hline Observations & 114 & 87 & 113 & 113 & 113 & 113 \\
R-squared & 0.969 & 0.957 & 0.954 & 0.963 & 0.969 & 0.971 \\
\hline * Estimation results with pooled OLS method. Robust standard errors clustered by country are in parentheses. All \\
regressions include controls for area, remoteness, export growth, size of trade, FDI, and year fixed effects. *** \\
p<0.01, ** p<0.05, * $\mathrm{p}<0.1$.
\end{tabular}

Table 16

Results with Overall Tariff Rates

\begin{tabular}{lllllll}
\hline & & & & \\
& Regulations & Finance & Entry & Exp & Infrastructure & Property \\
\hline RealGDP(PPP) & 0.979 & 1.011 & 1.091 & 0.982 & 0.998 & 1.004 \\
& $(0.029)^{* * *}$ & $(0.039)^{* * *}$ & $(0.034)^{* * *}$ & $(0.032)^{* * *}$ & $(0.029)^{* * *}$ & $(0.029)^{* * *}$ \\
OTRI & -0.034 & -0.225 & -0.171 & -0.239 & -0.243 & -0.256 \\
& $(0.066)$ & $(0.105)^{* *}$ & $(0.091)^{*}$ & $(0.066)^{* * *}$ & $(0.068)^{* * *}$ & $(0.073)^{* * *}$ \\
MAOTRI & -0.244 & -0.633 & -0.497 & 0.630 & -0.660 & -0.644 \\
& $(0.058)^{* * *}$ & $(0.376)^{*}$ & $(0.243)^{* *}$ & $(0.240)^{* *}$ & $(0.236)^{* * *}$ & $(0.199)^{* * *}$ \\
MAOTRI*Indicator & 0.111 & 0.079 & 0.017 & -0.292 & 0.323 & 0.068 \\
& $(0.059)^{*}$ & $(0.107)$ & $(0.019)$ & $(0.081)^{* * *}$ & $(0.166)^{*}$ & $(0.029)^{* *}$ \\
Indicator & 0.230 & 0.068 & -0.103 & 0.184 & 0.031 & -0.007 \\
& $(0.156)$ & $(0.272)$ & $(0.049)^{* *}$ & $(0.223)$ & $(0.442)$ & $(0.080)$ \\
\hline Observations & 181 & 153 & 180 & 180 & 180 & 177 \\
R-squared & 0.973 & 0.952 & 0.961 & 0.971 & 0.969 & 0.968 \\
\hline$*$ Estimation results with pooled OLS method. Robust standard errors clustered by country are in parentheses. All \\
regressions include controls for area, remoteness, export growth, size of trade, FDI, and year fixed effects. ${ }^{* * *}$ \\
$\mathrm{p}<0.01,{ }^{* *} \mathrm{p}<0.05,{ }^{*} \mathrm{p}<0.1$.
\end{tabular}

